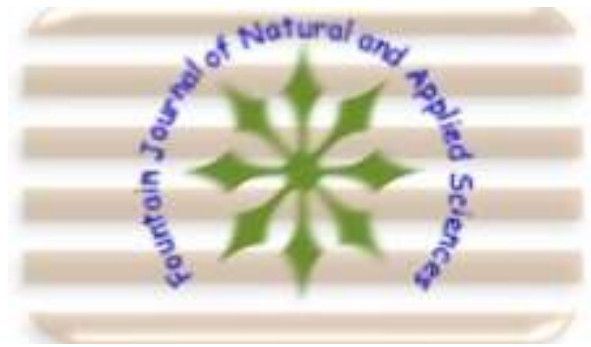

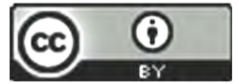

This work is licensed under Creative Commons Attribution 4.0 International License

DOI: $10.53704 /$ fujnas.v9i1.322

A publication of College of Natural and Applied Sciences, Fountain University, Osogbo, Nigeria. Journal homepage: www.fountainjournals.com ISSN: 2354-337X(Online),2350-1863(Print)

\title{
Synthesis, Structural Elucidation and Antimicrobial Activity of Metal (II) Polypyridyl Complexes of 2-Amino-4-(Methylthio) Butanoic Acid
}

\author{
${ }^{* 1}$ Rajee, A. O., ${ }^{2}$ Babamale. H. F., ${ }^{3}$ Aliyu, A. A., ${ }^{1}$ Lawal, A., ${ }^{4}$ Ayinla, S, O., ${ }^{5}$ Osunniran, W. A., ${ }^{6}$ Aliyu, \\ A. A. and ${ }^{6}$ Musa, I. \\ ${ }^{1}$ Department of Chemistry, University of Ilorin, Ilorin, Nigeria. \\ ${ }^{2}$ Department of Industrial Chemistry, University of Ilorin, Ilorin, Nigeria. \\ ${ }^{3}$ Department of Pure and Industrial Chemistry, Kogi State University, Anyigba, Kogi, Nigeria. \\ ${ }^{4 *}$ Department of Applied Sciences, Al-Hikmah University, Ilorin, Kwara, Nigeria. \\ ${ }^{5}$ Department of Chemical, Geological and Physical Sciences, Kwara State University, Malete, Kwara, Nigeria. \\ ${ }^{6}$ Department of Chemistry, faculty of Science, Nigerian Defense Academy, Kaduna, Nigeria
}

\begin{abstract}
The interaction of selected biometals with dinitrogen donor ligand, 1,10-phennathroline (phen) and amino acid, 2-amino-4-(methylthio)butanoic acid (methionine; met) resulted in isolation of three mononuclear complexes. The prepared complexes were characterized by diverse techniques including elemental and spectroscopic analysis. From the analytical and spectral data, octahedral geometry was proposed to the synthesized metal (II) complexes. Bonding of the metal ion through $\mathrm{N}^{-}$and $\mathrm{O}^{-}$donor atoms of the ligands is revealed by infrared studies. The compounds showed moderate solubility in distilled water and in some common organic solvents. In vivo evaluation of the antimicrobial activities of the metal complexes showed improved inhibitory activity against some micro-organisms as compared to the ligands, with $\mathrm{Co}(\mathrm{II})$ and $\mathrm{Cu}(\mathrm{II})$ complexes showing the highest activities against the fungi.
\end{abstract}

Keywords: antimicrobial; mixed ligands; amino acid; polypyridyl

\section{Introduction}

Drug resistance, especially antibiotics, is one of the most important threats to public health. Antibiotic-resistant infections can sometimes lead to serious ill health or even mortality (de Sousa et $a l, 2020)$. Therefore, considering the swift spread of multi-drug resistance, the design and development of new antimicrobial agents which act on newly adapted microorganisms has become a priority. The use of metals in medicine is in fact an ancient practice stretching back thousands of years. Metals are found to play an astonishing number and variety of roles in modern medicine. Metal-based drugs play an important role in medicine for the treatment of various diseases. Modern medicinal chemistry seeks to intentionally investigate the structure and properties of metal complexes for medicinal function has developed immensely. The focus is on the design of safe metallotherapeutics, due to their ability to overcome the developed cell resistance, their biological activity, their side-

\footnotetext{
*Corresponding author: Rajee, A. O.

Email address: olarajee@unilorin.edu.ng
} 
effects, their low solubility and the advantages over the organic drugs (Thakkar \& Thakkar, 2000; Shivankar \& Thakkar, 2003; Theophanides et al., 2003).

Design of complexes containing mixed ligands are established to be biologically active against pathogenic microorganisms (Thakkar \& Thakkar, 2000; Shivankar \& Thakkar, 2003), and polypyridyl as co-ligands in complexes, has shown promising biological activities (Howard-Lock, \& Lock, 1987). The chemistry of amino acid coordination compounds has always been an intriguing challenge to the inorganic chemists. this class of molecules have been found throughout the life science and vary tremendously in their function and complexity. These compounds play an essential part of metabolism and cellular signaling and as a part of drugs (Ozturk et al., 2014). Amino acids form coordination compounds that show significant enzymatic and biological activities (Perrin \& Agarwal, 1973; Sigel \& Sigel, 2002; Bodkhe et al., 2012).

In this work, we synthesized three ternary metal (II) complexes containing an amino acid, methionine ligand, and the heterocyclic ligand, 1,10-phennathroline (phen). Further insight into the bonding and possible geometrical structure has been made by microanalytical, IR, UV-vis spectral studies., as well as magnetic susceptibility measurements. The antimicrobial activities of the complexes against some selected Gram positive and Gram-negative bacteria and fungi were also reported. The knowledge gained from this study should be useful for the development of potentially new therapeutic agents for combating antibiotic resistance.
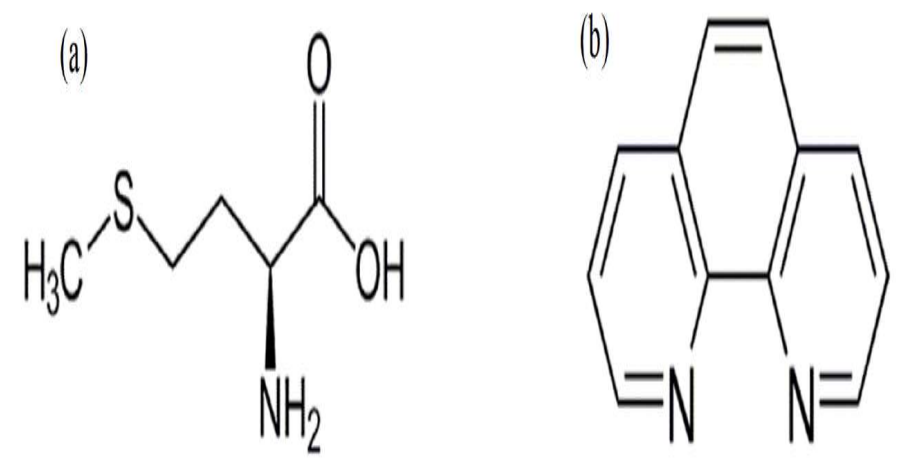

Figure 1: Structure of ligands (a) methionine (b) 1,10-phenanthroline

\section{Experimental}

Materials

2-amino-4-(methylthio)butanoic acid was purchased from Loba Chemie Pvt Ltd, analytical grade purity, while $\mathrm{Mn}$ (II), $\mathrm{Cu}$ (II) and $\mathrm{Co}$ (II) chlorides, 1,10-phenanthroline, dimethylsulfoxide, ethanol, and methanol, Muller Hinton agar, Nutrient agar were purchased from Acros and Merck Laboratories, analytical grade purity. Elemental analyses were carried out using the CHNS-O EA1110 Analyzer. Electronic spectra were recorded on a Shimadzu UVPC-3001 spectrophotometer. Infrared spectra were recorded on a FTIR Spectrophotometer Spectrum 2000, Perkin Elmer; using $\mathrm{KBr}$ pellets.

\section{Synthesis of Complexes \\ Synthesis of [Cu(phen)2(MET)] (1)}

Complex 1 was prepared according to the method described previously (Mohamed et al., 2012). Phen (0.360 g, $2 \mathrm{mmol})$ was mixed with $(0.170 \mathrm{~g}, 1 \mathrm{mmol})$ of $\mathrm{CuCl}_{2} \cdot 2 \mathrm{H}_{2} \mathrm{O}$ in $10 \mathrm{ml} 80 \%$ $(\mathrm{v} / \mathrm{v})$ of ethanol-water solution for about $10 \mathrm{~min}$ at room temperature. The aquamarine-colored precipitate appeared after adding copper salt. The precipitate was dried under vacuum and assumed to be $\left[\mathrm{Cu}(\text { phen })_{2} \mathrm{Cl}_{2}\right]$. Then, the precipitate $(247 \mathrm{~g}, 0.5$ mmol) was reacted with $(0.075 \mathrm{~g}, 0.5 \mathrm{mmol})$ of methionine in $10 \mathrm{ml}$ of $70 \%(\mathrm{v} / \mathrm{v})$ ethanol-water solution for about $4 \mathrm{~h}$ at $353 \mathrm{~K}$, until the volume of the reaction mixture was concentrated to ca. $2 \mathrm{ml}$. The concentrated deep green solution was allowed to stand at room temperature for slow evaporation. Green-blue prismatic crystals were obtained from the mother liquor.

FT-IR (KBr pellet, $\left.v \mathrm{~cm}^{-1}\right)$ : $3256\left(\mathrm{NH}_{2}\right), 3078$ (ArH), 2889, $2775\left(\mathrm{CH}_{2}\right), 1608(\mathrm{C}=\mathrm{O}), 1577,1454$ $(\mathrm{C}=\mathrm{C}, \mathrm{C}=\mathrm{N}), 594,520(\mathrm{Cu}-\mathrm{N}, \mathrm{Cu}-\mathrm{O})$. Elem. Anal. Calc. (\%) for $\mathrm{C}_{29} \mathrm{H}_{25} \mathrm{~N}_{5} \mathrm{O}_{2} \mathrm{SCu}$; C, 60.32; H, 4.52; N, 12.41. Found: C, 60.98; H, 4.41; N, 12.26. ESIMS $(m / z$ positive mode) Calc. 571.01, Found: 570.2 .

$\left[\mathrm{Mn}(\mathrm{phen})_{2}\right.$ (met)] (2). The complex was prepared using a procedure similar to that for $\mathbf{1}$ by using $\mathrm{MnCl}_{2} \cdot 4 \mathrm{H}_{2} \mathrm{O}$ instead of $\mathrm{CuCl}_{2} \cdot 2 \mathrm{H}_{2} \mathrm{O}$. Yield: $0.254 \mathrm{~g}, 57 \%$. FT-IR (KBr pellet, $\left.v \mathrm{~cm}^{-1}\right)$ : 3059(ArH), 2823, 2752( $\left.\mathrm{CH}_{2}\right), 1608(\mathrm{C}=\mathrm{O}), 1577$, $1454(\mathrm{C}=\mathrm{C}, \mathrm{C}=\mathrm{N}), 513,455(\mathrm{Mn}-\mathrm{N}, \mathrm{Mn}-\mathrm{O})$. Elem. 
Anal. Calc. (\%) for $\mathrm{C}_{29} \mathrm{H}_{25} \mathrm{~N}_{5} \mathrm{O}_{2} \mathrm{SMn} ; \mathrm{C}, 61.40 ; \mathrm{H}$, 4.28; N, 13.11. Found: C, 61.92; H, 4.48; N, 12.45 . ESI-MS ( $\mathrm{m} / \mathrm{z}$ positive mode) Calc. 562.24 , Found: 562.11 .

$\left[\mathrm{Co}(\text { phen })_{2}\right.$ (met)] (3). The complex was prepared using a procedure similar to that for $\mathbf{1}$ by using $\mathrm{CoCl}_{2} \cdot 6 \mathrm{H}_{2} \mathrm{O}$ instead of $\mathrm{CuCl}_{2} \cdot 2 \mathrm{H}_{2} \mathrm{O}$. Yield: $0.254 \mathrm{~g}, 46 \%$. FT-IR (KBr pellet, $\left.v \mathrm{~cm}^{-1}\right): 3375(\mathrm{~N}-$ $\mathrm{H}), \quad 3059(\mathrm{ArH}), 2823,2752\left(\mathrm{CH}_{2}\right), 1608(\mathrm{C}=\mathrm{O})$, 1577, 1454(C=C, $\mathrm{C}=\mathrm{N}), 513,455(\mathrm{Co}-\mathrm{N}, \mathrm{Co}-\mathrm{O})$. Elem. Anal. Calc. (\%) for $\mathrm{C}_{29} \mathrm{H}_{25} \mathrm{~N}_{5} \mathrm{O}_{2} \mathrm{SCo}$; C, 61.24; H, 4.41; N, 13.31. Found: C, 61.48; H, 4.45; $\mathrm{N}$, 12.36. ESI-MS $(\mathrm{m} / \mathrm{z}$ positive mode) Calc. 564.21, Found: 566.11.

\section{Results and Discussion}

The percent composition of carbon, hydrogen, nitrogen and metal were determined to establish the composition of the coordination compounds. The results are listed in Table I. The mixed-ligand complexes were prepared according to the following general equations:

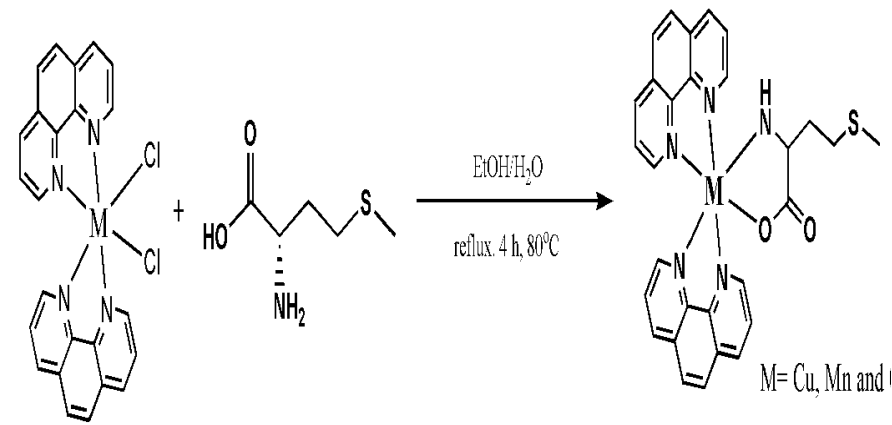

Figure 2: Synthetic scheme for the preparation of the complexes

\section{Infrared Spectra}

The IR spectra of the complexes shows the characteristic bands of the ligands involved (Table 2). The amino acid, methionine exhibit $v\left(\mathrm{NH}_{2}\right)$ at $3365 \mathrm{~cm}^{-1}, v_{\mathrm{s}}(\mathrm{COO}-)$ and $v_{\mathrm{as}}\left(\mathrm{COO}^{-}\right)$at $1410 \mathrm{~cm}^{-1}$ and $1621 \mathrm{~cm}^{-1}$, respectively. The peaks at $3365 \mathrm{~cm}^{-}$ ${ }^{1}$ and $3347 \mathrm{~cm}^{-1}$ which is due to asymmetric and symmetric stretching vibrations of $\mathrm{N}-\mathrm{H}$ in a primary amine group which shows that the group of zwitterions of free ligand is deprotonated to $-\mathrm{NH}_{2}$ and participated in the coordination with metal ion. For the complexes, the stretching vibration of $v_{\mathrm{s}}\left(\mathrm{COO}^{-}\right)$and $v_{\mathrm{as}}\left(\mathrm{COO}^{-}\right)$appear in the range 1400 $1405 \mathrm{~cm}^{-1}$ and $1570-1598 \mathrm{~cm}^{-1}$, respectively. The $\mathrm{COO}^{-}$asymmetric and symmetric absorption bands are at relatively lower frequencies compared to those of free ligand. The reduction of absorption frequencies may be due to the formation of coordination bond through oxygen atom of $-\mathrm{COO}^{-}$ group with metal ion (Patil et al., 2011). No free carboxylic $(\mathrm{COOH})$ groups could be detected from the IR spectral data, indicating coordination of all of the studied metal ions to the carboxylate anions. Since there is no significant absorption band at about $v>3450 \mathrm{~cm}^{-1}$ for $v(\mathrm{O}-\mathrm{H})$ absorption in any of the complexes, we can conclude that there is no water molecule in the complexes as coordinated water or as water of crystallization.

Methionine $\left(v, \mathrm{~cm}^{-1}\right): 3414, v_{\text {str }}\left(\mathrm{NH}_{3}{ }^{+}\right) 2914 v_{\text {str }}$ $(\mathrm{C}-\mathrm{H}), 1630 v_{\mathrm{as}}\left(\mathrm{NH}_{3}{ }^{+}\right), 1580 v_{\mathrm{as}}\left(\mathrm{COO}^{-}\right), 1516 v_{\mathrm{sb}}$ $\left(\mathrm{NH}_{3}{ }^{+}\right), 1413 v_{\mathrm{s}}\left(\mathrm{COO}^{-}\right), 1220 v_{\mathrm{b}}(\mathrm{S}-\mathrm{CH})$.

Table 1: Empirical formula, molecular weight, elemental analysis data and molar conductance of complexes

\begin{tabular}{|c|c|c|c|c|c|c|c|}
\hline \multirow[t]{2}{*}{ Complex } & \multirow[t]{2}{*}{$\begin{array}{l}\text { Empirical } \\
\text { formula }\end{array}$} & \multirow[t]{2}{*}{$\begin{array}{l}\text { Molecular } \\
\text { weight }\end{array}$} & \multicolumn{3}{|c|}{$\begin{array}{l}\text { Elemental analysis } \\
\text { Found (Calculated) }\end{array}$} & \multirow{2}{*}{$\begin{array}{l}\text { Melting } \\
\text { point } \\
\left({ }^{\circ} \mathrm{C}\right)\end{array}$} & \multirow[t]{2}{*}{ Colour } \\
\hline & & & $\% \mathrm{C}$ & $\% \mathbf{H}$ & $\% \mathbf{N}$ & & \\
\hline$[\mathrm{Cu}($ phen)2(met)] & $\mathrm{C}_{29} \mathrm{H}_{25} \mathrm{~N}_{5} \mathrm{O}_{2} \mathrm{SCu}$ & 570.20 & $\begin{array}{l}60.98 \\
(60.32)\end{array}$ & $\begin{array}{l}4.41 \\
(4.52)\end{array}$ & $\begin{array}{l}12.26 \\
(12.41)\end{array}$ & $266-268$ & Green \\
\hline$[$ Mn(phen)2(met)] & $\mathrm{C}_{29} \mathrm{H}_{25} \mathrm{~N}_{5} \mathrm{O}_{2} \mathrm{SMn}$ & 562.11 & $\begin{array}{l}61.92 \\
(61.50)\end{array}$ & $\begin{array}{l}4.48 \\
(4.28)\end{array}$ & $\begin{array}{l}12.45 \\
(13.11)\end{array}$ & $248-250$ & Cream \\
\hline$[$ Co(phen)2(met)] & $\mathrm{C}_{29} \mathrm{H}_{25} \mathrm{~N}_{5} \mathrm{O}_{2} \mathrm{SCo}$ & 566.11 & $\begin{array}{l}61.48 \\
(61.24)\end{array}$ & $\begin{array}{l}4.45 \\
(4.41)\end{array}$ & $\begin{array}{l}13.31 \\
(12.45)\end{array}$ & $254-256$ & Blue \\
\hline
\end{tabular}


Table 2: Infrared Spectral data of the complexes $\left(\mathrm{cm}^{-1}\right)$

\begin{tabular}{|c|c|c|c|c|c|c|}
\hline & $\mathrm{v}_{\mathrm{s}}\left(\mathrm{COO}^{-}\right)$ & $v_{\text {as }}\left(\mathrm{COO}^{-}\right)$ & $v(\mathrm{~N}-\mathrm{H}) \mathrm{str}$ & $v(C=N)$ & $v(M-O)$ & $v(M-N)$ \\
\hline$\left[\mathrm{Cu}(\text { phen })_{2}\right.$ (met)] & $1400 \mathrm{~m}$ & $1610 \mathrm{~s}, \mathrm{~b}$ & $3341 \mathrm{~m}$ & 1498 & $466 \mathrm{~m}$ & $414 \mathrm{w}$ \\
\hline [Zn(phen)2(met)] & $1465 \mathrm{~m}$ & $1620 \mathrm{~s}$ & $3232 \mathrm{~m}$ & 1520 & $481 \mathrm{~m}$ & $410 \mathrm{w}$ \\
\hline$\left[\operatorname{Co}(\text { phen })_{2}\right.$ (met)] & $1411 \mathrm{~m}$ & $1615 \mathrm{~s}, \mathrm{~b}$ & $3420 \mathrm{~m}$ & 1615 & $476 \mathrm{~m}$ & $416 \mathrm{w}$ \\
\hline
\end{tabular}

KEY: s (strong), m (medium), w (weak)

From the foregoing band positions of $v\left(\mathrm{NH}_{2}\right)$, $v\left(\mathrm{COO}^{-}\right), v(\mathrm{M}-\mathrm{O})$ and $v(\mathrm{M}-\mathrm{N})$ and comparison with similar compounds (Amolegbe et al., 2014; de Sousa et al, 2020), it may be concluded that the involved amino acid in the complexes are bidentate coordinating through the $-\mathrm{NH}_{2}$ and $\mathrm{COO}^{-}$groups.

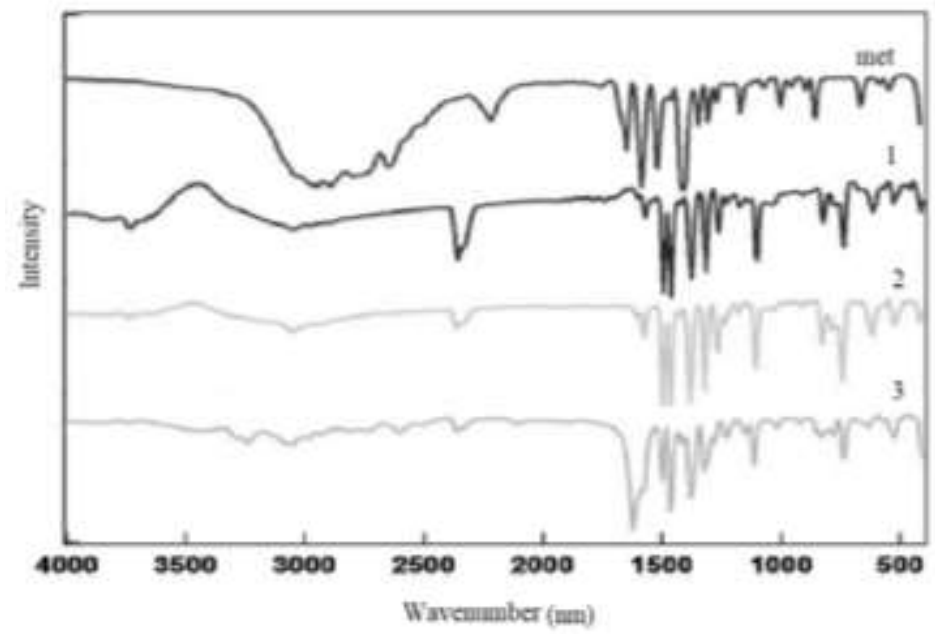

Figure 3: Infrared spectra of compounds

\section{Electronic Spectra}

The electronic absorption spectra of the mixed metal complexes and their characteristics absorption bands with tentative assignments were recorded in dimethylformamide at various concentrations and are presented in Table 3. The assignments have been done on the basis of some standard references (Singh et al., 1995; Amolegbe et al., 2014; Vusak et al., 2017). The absorption bands between 200 and $400 \mathrm{~nm}$ were observed for the organic part of the complexes and that of $>$ $400 \mathrm{~nm}$ was due to the metal ion. The bonding pattern of the complexes were similar in most of the cases. The bands due to $\pi \rightarrow \pi^{*}$ transition in all the metal complexes at $\sim 236-253 \mathrm{~nm}$ were broad. Whereas in the ligand, it was found at about $224 \mathrm{~nm}$.

Table 3: Electronic Spectra Data of the complexes

\begin{tabular}{lll}
\hline & $\lambda$ max $\mathbf{( n m )}$ & Assignment \\
\hline Methionine & 224 & $\pi \rightarrow \pi^{*}$ \\
& 262 & $\mathrm{n} \rightarrow \sigma^{*}$ \\
& 300,331 & $\mathrm{n} \rightarrow \pi^{*}$ \\
{$[$ Cu(phen)2(met)] } & 253, & $\pi \rightarrow \mathrm{n}^{*}$ \\
& 298, & $\mathrm{n} \rightarrow \sigma^{*}$ \\
& 338,365 & $\mathrm{n} \rightarrow \pi^{*}$ \\
& 413 & $\mathrm{~d} \rightarrow \mathrm{d}$ \\
{$[$ Mn(phen)2(met)] } & 238 & $\pi \rightarrow \mathrm{n}^{*}$ \\
& 296 & $\mathrm{n} \rightarrow \sigma^{*}$ \\
& 341,349 & $\mathrm{n} \rightarrow \pi^{*}$ \\
& 604 & $\mathrm{~d} \rightarrow \mathrm{d}$ \\
{$[$ Co(phen)2(met)] } & 236 & $\pi \rightarrow \mathrm{n}^{*}$ \\
& 297 & $\mathrm{n} \rightarrow \sigma^{*}$ \\
& 346,337 & $\mathrm{n} \rightarrow \pi^{*}$ \\
\hline
\end{tabular}

The presence of the absorption band at $\sim 265-$ $295 \mathrm{~nm}$ in the complexes was due to $n \rightarrow \sigma^{*}$ transitions that was observed at $262 \mathrm{~nm}$ in ligand. The $n \rightarrow \pi^{*}$ transition bands were observed at 325 $344 \mathrm{~nm}$ (at 300 and $331 \mathrm{~nm}$ in ligand) in all the metal complexes. The presence of $\pi \rightarrow \pi^{*}, n \rightarrow \pi^{*}$ and $n \rightarrow \sigma^{*}$ bands in all the complexes indicate the presence of the functional groups of the parent ligands (e.g. $-\mathrm{C}=\mathrm{O},-\mathrm{NH}_{2}$ and $\mathrm{C}-\mathrm{S}$ ) intact in the complexes. A large shifting of the absorption bands in the complexes and appearing of a new band for $\mathrm{d}-\mathrm{d}$ transitions also indicate the probability of forming $\mathrm{M}^{+} \leftarrow \mathrm{L}$ coordination bonds in the complexes. 
Transition metal complexes are generally colored and this color arises due to the absorption of light in visible region. Therefore, the broad bands centering around 450, 515 and $514 \mathrm{~nm}$ in $\mathrm{Cu}$ (II), Mn (II) and Co (II) complexes respectively are clearly due to the $\mathrm{d}-\mathrm{d}$ electronic transitions, which causes color of the complexes.

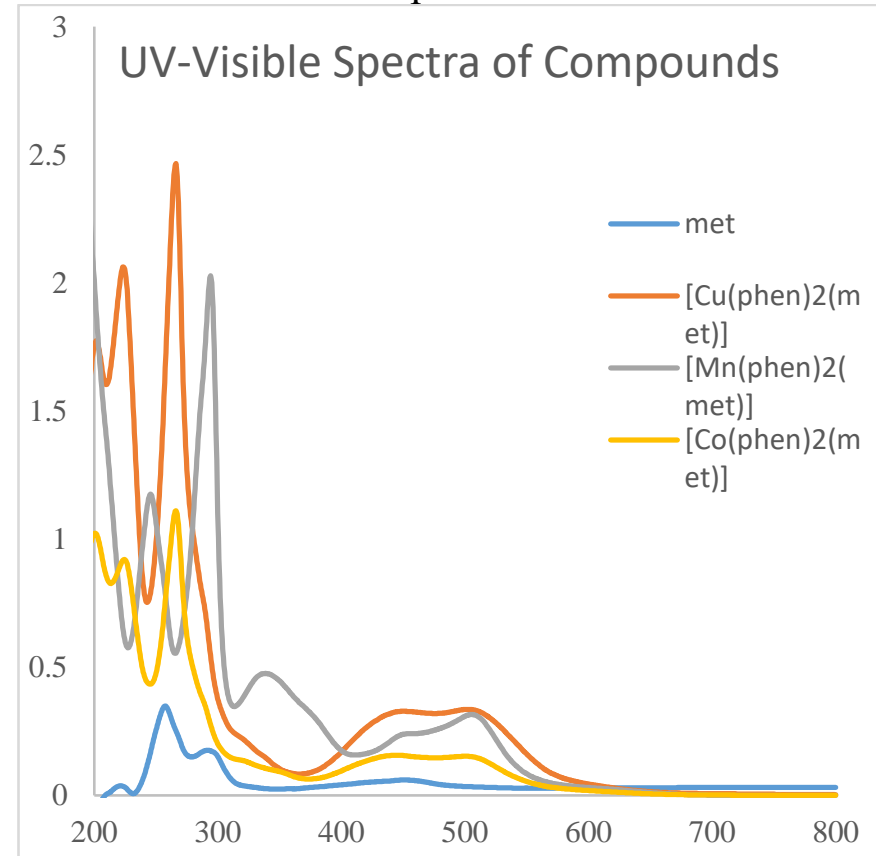

Figure 4: Electronic spectra of compounds

From the foregoing data the structure of the complexes can be postulated as follows (Fig. 5)

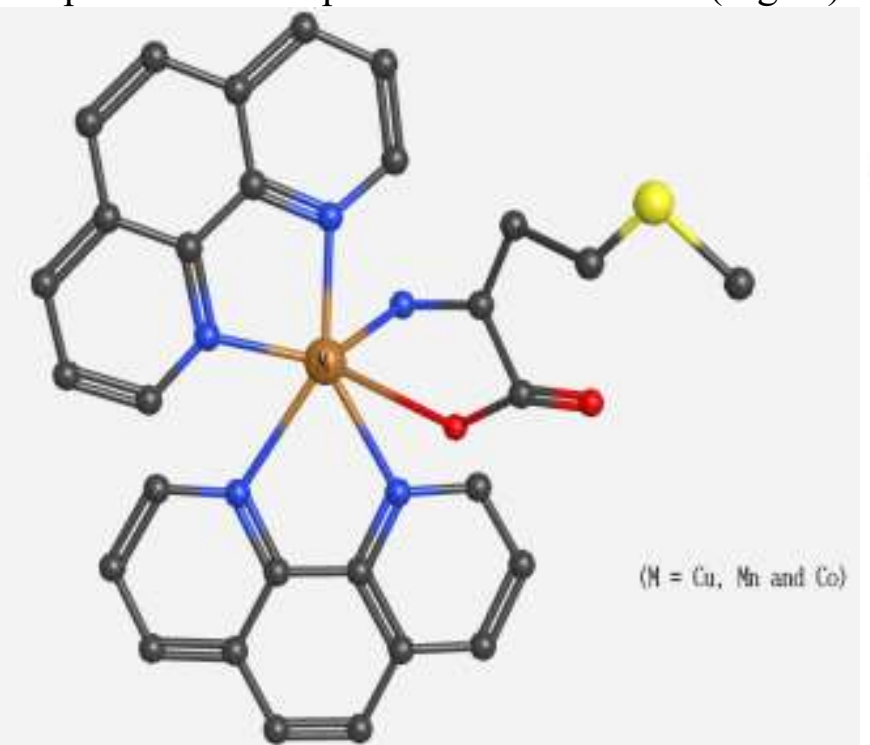

Figure 5: Optimized Structure of metal complexes (1-3)

\section{Antimicrobial Activity}

The prepared metal complexes were evaluated for their antimicrobial potential against B. subtilis, S. aureus (gram-positive), E. coli and P. aeruginosa (gram-negative) and A. niger and C. albicans (strains of fungi) using the disc diffusion method. The results of the screening of the prepared complexes are recorded in Table 4. The solvent and metals ions used showed no growth inhibition, suggesting that they do not interfere in the antimicrobial activity of the complexes.

The methionine has moderate activity with $\mathrm{S}$. aureus, E. coli, P. aeruginosa and B. subtilis. The complexes exhibited significantly improved antibacterial activity against the tested microbial strains in comparison to the free ligand.

The $\mathrm{Cu}(\mathrm{II})$ and $\mathrm{Co}(\mathrm{II})$ complexes displays higher inhibitory activity with Gram positive bacteria than negative ones. It is clearly observed that the complexes are also very active against the fungi $\mathrm{C}$. albicans and A. niger. However, $\mathrm{Mn}$ (II) complexes show a higher antimicrobial activity than the $\mathrm{Co}(\mathrm{II})$ against the fungi. The mixed complexes of $\mathrm{Co}(\mathrm{II})$ and $\mathrm{Cu}(\mathrm{II})$ of methionine shows the highest antimicrobial inhibitory activities overall. Thus, the antimicrobial activity increases on going from ligand to complexation.

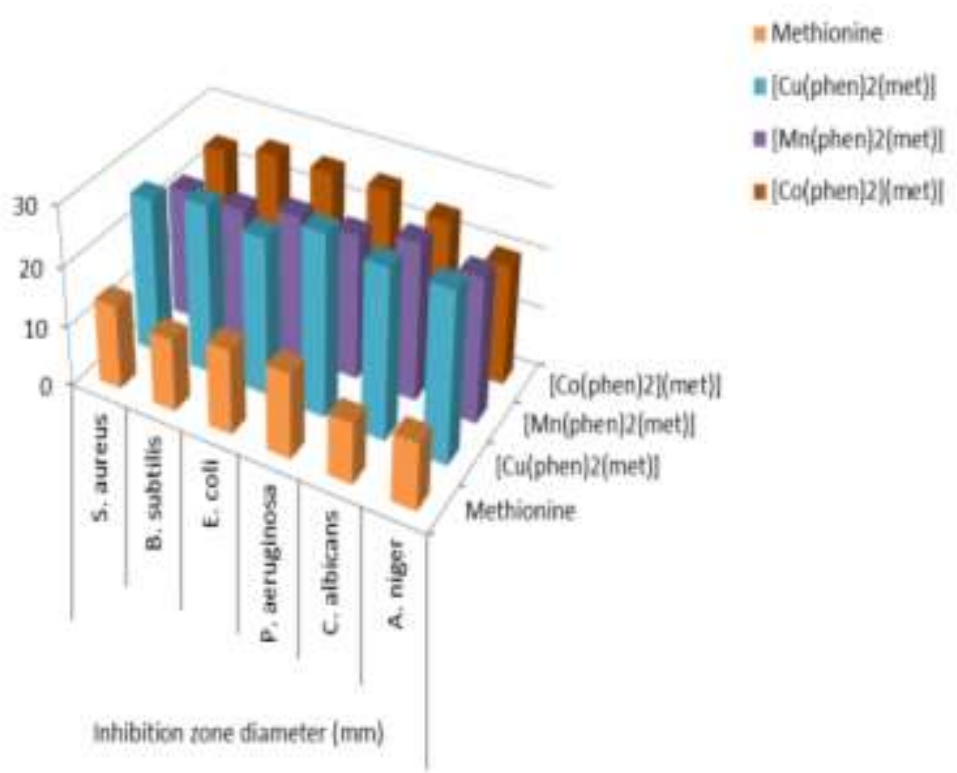

Figure 6: Chart showing the inhibition zones of ligand and complexes 
Table 4: Results of antimicrobial screening of ligand and metal complexes

\begin{tabular}{lcccccc}
\hline & \multicolumn{7}{c}{ Inhibition zone diameter (mm) } & & \\
\hline & $S$. & $B$. & $E$. & $P$. & $C$. & $A$. \\
aureus & subtilis & coli & aeruginosa & albicans & niger \\
Methionine & 14 & 12 & 14 & 14 & 10 & 11 \\
{$[$ Cu(MET)(phen)2] } & 26 & 28 & 26 & 30 & 28 & 28 \\
{$[$ Mn(MET)(phen)2] } & 21 & 22 & 24 & 22 & 26 & 24 \\
{$[$ Co(MET)(phen)2] } & 24 & 28 & 26 & 26 & 22 & 21 \\
\hline
\end{tabular}

In complexes, the part sharing of the positive charge on the central metal atom with the ligands reduces the polarity of the metal atom and there is an electron delocalization over the whole chelated ring (Singh et al., 1995; Thangadurai \& Natarajan, 2001). Indeed, typical chelation tends to improve the lipophilic character of the central atom, which subsequently favours its permeation through the lipid layers of the cell membrane and obstructing the metal binding sites on enzymes of microorganism (Al-Amiery et al., 2012). Thus, we infer that complexation increases the antimicrobial activity.

\section{Conclusion}

Summarily, the synthesis and the characterization of three mononuclear M(II) complexes with the amino acid methionine, as ligands in the presence of the nitrogen-donor ligand, phen has been discussed. Based on the results of physico-chemical and spectral techniques, the prepared complexes possess an octahedral geometry. The in vitro antimicrobial screening of the compounds were investigated. The results revealed that the mixed complexes showed improved inhibitory activity than the parent ligand. This is attributed to the chelation, which reduces the polarity of metal ion due to partial sharing of its positive charge with donor ligands and also due to the delocalization of $\pi$ electrons over while, chelate ring.

\section{References}

Abdulrahman, F. I., Akan, J. C., Sodipo, O. A. \& Onyeyilli, P. A. (2010). Effect of aqueous root bark extract of Vitexdomina sweet on hematological paramenters in rats. Journal of American of Science. 6, 8-12.

Alsheikh-Ali, A. A., Kuvin, J. T. \& Karas, R. H. (2004). Risk of adverse events with fibrates. American. Journal of Cardiology, 94, 935-8.

Anaga, A. O. \& Oparah, N. Q. (2009). Investigation of the methanol root extract of Cochlospermum planchonii for pharmacological activities in vitro and in vivo. Pharmaceautical Biology, 47, 1027-1034.

Arranz, S., Chiva-Blanch, G., Valderas-Martínez, P., Medina-Remón, A., Lamuela-Raventós, R. M. \& Estruch, R. (2012). Wine, beer, alcohol and polyphenols on cardiovascular disease and cancer. Nutrients 4, 759-781.

Ashafa, A. O. T. \& Yakubu, M. T. (2009). Effect of aqueous leaf extract from the leaves of Chrysocoma ciliate $L$ on some biochemical parameters of Wistar rats. African Journal of Biotechnology, 8, 1425-1430.

Benoit-Vical, F., Valentin, A., Mallié, M., Bastide, J. M. \& Bessière, J. M. (2001). Antiplasmodial activity of Cochlospermum planchonii and $C$. tinctorium tubercle essential oils. Journal of Essential Oil Research, 13, 65-67.

Blench, R. \& Dendo, M. (2007). Hausa names for plants and trees. Draft prepared for comment 
only 2 (Ed.), United Kingdom, Cambridge.

Bren, U., Mojzer, E. B., Hrncie, M. K., Skerget, M. \& Knez, Z. (2016). Polyphenols: Extraction methods, antioxidative actions, bioavailability and anticancinogenic effects. Molecules, 21, 901; doi:10.3390/molecules21070901.

Deori, M., Boruah, D. C., Devi, D. \& Devi, R. (2014). Antioxidant and antigenotoxic effects of pupae of the muga silk worm Antheraeaassamensis. Food Bioscience, 5, 108 114.doi:10.1016/j.fbio.2013.12.001.

Espín, J. C., García-Conesa, M. T. \& TomásBarberán, F. A. (2007). Nutraceuticals: facts and fiction. Phytochemistry, 68, 2986-3008

Ezeja, M. I. \& Anaga, A. O. (2010). Anti-diarrhoeal activities of the methanolic root bark extract of Cochlospermum planchonii (Hook f). International Journal of Toxicology and Pharmacology Research, 2, 40-45.

Friedwald, W. T., Levy, R. J. \& Fredrickson, D. S. (1972). Estimation of concentration of the preparative ultracentrifuge, Clinical Chemistry, 18, 499-509.

Geetha, G., Kalavalarasariel, G. P. \& Sankar, V. (2011). Antidiabetic effect of Achyranthes rubrofusca leaf extracts on alloxan induced diabetic rats. Pakistan Journal of Pharmaceutical Sciences, 24 (2), 193-199.

Grassi, D., Aggio, A., Onori, L., Croce, G., Tiberti, S., Ferri, C., Ferri, L. \& Desideri, G. (2008). Tea, flavonoids and NO-mediated vascular reactivity, Journal of Nutrition, 138, 1554S$1560 \mathrm{~S}$.

Grassi, D., Desideri, G., Tiberti, S. \& Ferri, C. (2009a). Oxidative stress, endothelial dysfunction and prevention of cardiovascular diseases, AgroFOOD Industry Ii-tech, 20, 76-79.

Grassi, D., Desideri, G., Croce, G., Tiberti, S., Aggio, A. \& Ferri, C. (2009b). Flavonoids, vascular function and cardiovascular protection. Curr. Pharm. Des, 15, 1072-1084.

Grundy, S. M., Cleeman, J. I., Merz, B. C. N., Brewer, H. B., Clark, L. T., Hunninghake, D. B., Pasternak, R. C., Smith, S. C. \& Stone, N. J. (2004). Implications of recent clinical trials for the National Cholesterol Education Program Adult Treatment Panel III guidelines.
Circulations 110 (2), 227-239. DOI:

10.1161/01.CIR.0000133317.49796.0E

Keshetty, V., Pabba, S., Gudipati, R., Kandukuri, J. M. \& Allenki, V. (2009). Antihyperlipidemic Activity of methanolic extract of Garlic (Allium sativum L.) in Triton X-100 induced hyperlipidemic rats. Journal Pharmacy Researcgh, 2 (5), 777-80.

Kumar, V., Khan, M. M., Khanna, A. K., Khanna, A. K., Singh, R., Singh, S., Chander, R., Mahdi, F, Sexana, J. K. \& Singh, R. K. (2010). Lipid lowering activity of Anthocephalus indicus root in hyperlipidemic rats. Evidence Based Complementary Alternative Medicine, 7(3):317-322, DOI: 10.1093/ecam/nen001.

Huang, P. L. (2009). A comprehensive definition for metabolic syndrome. Disease Models and Mechanisms, 2:231-237; DOI: $10.1242 / \mathrm{dmm} .001180$.

Isah, Y., Ndukwe, I. G. \& Ayo, R. G. (2013). Phytochemical and antimicrobial analyses of stem-leaf of Cochlospermum planchonii. Journal of Medicinal Plant and Herbal Theraphy Research, 1, 13-17.

Jamuna, D. \& Rajkumar, J. (2014). Effect of Ambrex (A Herbal Formulation) on Hematological variables in hyperlipidemic Rats. Pakistan Journal of Biological Sciences, 17, 740743.

Jung, U. J., Lee, M. K., Park, Y. B., Kang, M. A. \& Choi, M. S. (2006). Effect of citrus flavonoids on lipid metabolism and glucose-regulating enzyme mRNA levels in type-2 diabetic mice. International Journal of Biochemistry and Cell Biology, 38, 1134-1145.

Kaur, G. \& Meena, C. (2013). Evaluation of antihyperlipidemic potential of combinatorial extract of Curcumin, Piperine, and Quercetin in triton-induced hyperlipidemia in rats. Science. International 1 (3), 57-63.

Kwaan, H. C. (1992). Changes in blood coagulation, platelet function and plasminogen plasmin system in diabetes, Diabetics 41 (2), 3235.

Lee, C. Y., Kim, K. C., Park, H. W., Song, J. H. \& Lee, C. H. (2004). Rheological properties of 
erythrocytes from male hypercholesterolemia. Microvascular Research, 67: 133-138.

Lichtenstein, A. H., Appel, L. J., Brands, M., Carnethon, M., Daniels, S., Franch, H. A., Franklin, B., Kris-Etherton, P., Harris, W. S., Howard, B., Karanja, N., Lefevre, M., Rudel, L., Sacks, F., Van Horn, L., Winston, M. \& Wylie-Rosett, J. (2006). Diet and lifestyle recommendations revision 2006 - a scientific statement from the Am Hrt Association Nutrition Committee. Circulation 114 (1), 82-96

Mehta, L. K., Balaraman, R., Amin, A. H., Bafna, P. A. \& Gulati, O. D. (2003). Effect of fruits of Moringa oleifera on the lipid profile of normal and hypercholesterolaemic rabbits. Journal of Ethnopharmarcy, 86, 191-5.

Miller, M. (2009). Dyslipidemia and cardiovascular risk: the importance of early prevention. QJM, 102(9), 657-667.

Nafiu, M. O., Akanji, M. A. \& Yakubu, M. T. (2011). Phytochemical and mineral constituents of Cochlospermum planchonii (Hook. Ef. x Planch) Root. Bioresearch Bulletin, 5, 51-56.

Program NCE. (2002). Third report of the National Cholesterol Education Program (NCEP) expert panel on detection, evaluation, and treatment of high blood cholesterol in adults (adult treatment panel III) final report.

Rajput, M. S., Balekar, N. \& Jain, D. K. (2014). Lagenaria siceraria ameliorates athero-matous lesions by modulating HMG-CoA reductase and lipoprotein lipaseenzymes activity in hypercholesterolemic rats. Journal of Acute Diseases, 3 (1), 14-21.

Talayero, B. G. \& Sacks, F. M. (2011). The role of triglycerides in atherosclerosis, Current Cardiology Report, 13 (6), 544-552.

Tangney, C. \& Rasmussen, H. E. (2013). Polyphenols, inflammation, and cardiovascular disease. Current Atherosclerosis Report, 15 (5), 324.

Thanga, K., Kumari S, Packia, L. M., Muthukumarasamy, S. \& Mohan VR. (2013). Antihyperlipidemic effect of ethanol extract of whole plant of Canscora perfoliata Lam in Triton X-100 induced hyperlipidemic rats. International Journal of Advance Research, 1
(5), 166-170.

Togola, A, Austerheim, I., Theïs, A., Diallo, D. \& Paulsen, B. S. (2008). Ethnorpharmacological uses of Erythrina senegalensis: A comparison of three areas in Mali; and a link between traditional knowledge and modern biological science. Journal of Ethnobiology and Ethnomedicine, 4(6), 1-9.

Tresserra-Rimbau, A., Rimm, E. B., MedinaRemón, A., Martínez-González, M. A., De la Torre, R., Corella, D., Salas-Salvadi, J., GomezGracia, E, Lapetra, J., Aros, F., Fiol, M., SerraMagem, L., Pinto, X., Saez, G. T., Basora, J., Sorli, J. V., Martinez, J. A., Vinyoles, E., RuizGutierrez, V., Estrush, R. \& LamuelaRaventos,R. M. (2014). Inverse association between habitual polyphenol intake and incidence of cardiovascular events in the PREDIMED study. Nutrition Metabolism Cardiovascular Diseases, 24 (6), 639-647.

Tsao, R. (2010). Chemistry and biochemistry of dietary polyphenols. Nutrients 2, 1231-1246.

Venkatesan, N., Devaraj, S. N. and Devaraj, H. (2003). Increased binding of LDL and VLDL to apo B, E receptors of hepatic plasma membrane of rats treated with Fibernat. European Journal of Nutrition, 42 (5), 262-271.

Villaseñor, J. L. (2016). Checklist of the native vascular plants of Mexico. Revista Mexicana de Biodiversidad, 87 (3):559-902.

Vonthron-Sénécheau, C. V, Weniger, B, Ouattara M, Tra, B. F, Kamenan A, Lobstein, A., Brun, R. and Anton R. (2003). In vitro antiplasmodial activity and cytotoxicity of ethnobotanically selected Ivorian plants. Journal of Ethnopharmcy, 87, 221-225.

Yakubu, M. T., Akanji, M. A. \& Nafiu, M. O. (2010). Pharmacology Anti-diabetic activity of aqueous extract of Cochlospermum planchonii root in alloxan-induced diabetic rats. Cameroon Journal of Experimental Biology, 6 (20), 91100.

Yokozawa, T., Cho, E. J. \& Sasaki, S. (2006). The protective role of Chinese prescription kangenkaryu extract on diet-induced hypercholesterolemia in rats. Biol and Pharma Bulletin., 29 (4), 760-765. 